\title{
Performa Berahi Sapi PO Berbagai Umur yang Disinkronisasi Menggunakan Medroxy Progesterone Acetate di Satker Kendal
}

\section{Estrus Performance of Ongole Grade Cow at Different Age Syncronized using Medroxy Progesterone Acetate in Satker Kendal}

\author{
Mustagfiroh*, Sutiyono dan E. Kurnianto \\ Fakultas Peternakan dan Pertanian Universitas Diponegoro, Semarang, 50275 \\ *E-mail: mustagfiroh96@gmail.com
}

(Diterima: 29 November 2017; Disetujui: 15 Februari 2018)

\begin{abstract}
ABSTRAK
Tujuan penelitian ini untuk menganalisis performa berahi sapi Peranakan Ongole (PO) yang disinkronisasi dengan Medroxy Progesterone Acetate (MPA). Materi penelitian adalah 53 ekor sapi PO betina. Sapi-sapi dibagi berdasarkan umur menjadi 3 kelompok yaitu 2-5, >5-9 dan $>9-12$ tahun, kemudian sapi disinkronisasi menggunakan MPA dengan dosis $50 \mathrm{mg}$ per ekor. Parameter yang diamati adalah jumlah sapi yang berahi, kecepatan berahi dan lama berahi. Data banyaknya sapi yang berahi dianalisis menggunakan analisis deskriptif sedangkan data kecepatan berahi dan lama berahi masing-masing kelompok umur dianalisis menggunakan one way anova dengan bantuan progam SPSS. Hasil penelitian menunjukkan persentase respon berahi sapi yang disinkronisasi menggunakan MPA pada masing-masing kelompok umur 20\%, 50\% dan 35\%. Hasil analisis kecepatan berahi dan lama berahi antar kelompok umur sapi yang disinkronisasi dengan MPA menunjukkan tidak ada perbedaan. Simpulan penelitian adalah sinkronisasi menggunakan MPA tidak memberi perubahan terhadap performa berahi sapi PO berbagai umur.
\end{abstract}

Kata kunci: performa berahi, progesteron, Sapi Peranakan Ongole (PO), sinkronisasi berahi, umur

\section{ABSTRACT}

The purpose of this study was to analyze the performance of Ongole Grade cow (PO) synchronized with Medroxy Progesterone Acetate (MPA). The material used was 53 female PO. The cow were divided by age into 3 groups that were 2-5, >5-9 and >9-12 years, then the cow was synchronized using MPA at a dose of $50 \mathrm{mg}$ per head. The parameters observed were the number of estrus cow, the speed of estrus and the length of estrus. The data of a number of cows showing estrus was analyzed by using descriptive analysis while the data of estrus speed and length of estrus in each age group were analyzed by using one-way classification with SPSS program. The results showed that the percentage of cow responses synchronized by MPA in each age group was 20\%, 50\%, and 35\%. The speed of estrus and length of estrus among age groups of cattle synchronized with MPA showed no difference. In conclusions synchronized by MPA did not give a significant effect on estrus performance of Ongole Grade cow at a different age.

Keywords: age, estrus performance, estrus synchronization, Ongole Grade Cow (PO), progesterone

\section{PENDAHULUAN}

SapiPeranakan Ongole(PO) merupakan aset genetik sapi lokal Indonesia. Sapi PO banyak diternakkan oleh rakyat karena kemampuannya bertahan pada suhu tropis, mampu mencerna pakan berserat tinggi dengan baik dan induk sapi PO memiliki kelebihan aktivitas reproduksi yang cepat kembali normal setelah beranak (Pane,1993). Tahun 2012 populasi sapi potong di Jawa Tengah sebanyak 2.051.407 ekor dan tahun 2016 populasinya menurun menjadi 1.682 .449 ekor (Badan Pusat Statistik Jakarta Pusat, 2016). Populasi sapi potong yang menurun dengan jumlah permintaan daging yang meningkat 
menyebabkan banyaknya kasus pemotongan sapi betina untuk memenuhi permintaan daging. Pemotong sapi lokal betina produktif di Malang per tahun mencapai 200.000 ekor (Soejosopoetro, 2011).

Satuan kerja (Satker) Sumberejo Kendal adalah unit kerja Balai Pembibitan dan Budidaya Ternak Ruminansia yang mengembangkan pembibitan sapi PO dengan tujuan menghasilkan bakalan dan bibit sapi PO yang berkualitas. Ditinjau dari produktivitas sapi di Satker Sumberejo Kendal tergolong rendah. Rendahnya produktivitas dikarenakan banyak induk sapi yang dikawinkan dengan teknologi inseminasi buatan (IB) tidak berhasil sehingga dalam setahun banyak induk sapi tidak dapat menghasilkan anakan. Sinkronisasi berahi merupakan salah satu teknologi reproduksi untuk membuat berahi sekelompok sapi secara bersamaan. Kelebihan dari sinkronisasi berahi mampu meningkatkan efisiensi dalam pelaksanaan inseminasi buatan (IB) dan memudahkan peternak dalam deteksi berahi (Rizal dan Herdis, 2008). Sinkronisasi berahi merupakan upaya peternak untuk memunculkan berahi bersamaan pada sekelompok ternak betina (Sutiyono et al., 2014). Sinkronisasi dengan progesteron memiliki prinsip yaitu menghambat sekresi LH dan FSH dari adenohipofisis sehingga proses pematangan folikel de Graaf dan ovulasi sel telur terhambat. Lama periode pemberian hormon progesteron pada ternak sapi biasanya 14 hari sampai 21 hari (Britt, 1987). Timbulnya berahi pada sapi yang disinkronisasi dipengaruhi oleh banyak faktor, salah satunya adalah umur. Umur sapi yang masih muda memiliki respon sinkronisasi yang berbeda dengan sapi yang sudah tua (Hastono, 2000). Umur induk sapi tua menyebabkan kemampuan organ reproduksi menurun yang berakibat pada terganggunya sistem hormonal (Zainudin et al. 2015).

Penelitian ini bertujuan untuk mengetahui performa berahi pada berbagai umur sapi yang disinkronisasi berahi dengan medroxy progesterone acetate $50 \mathrm{mg} / \mathrm{ekor}$

Hipotesis penelitian adalah performa berahi kelompok umur sapi PO yang muda lebih baik daripada yang tua.

\section{METODE}

\section{Tempat Penelitian}

Penelitian dilakukan dengan metode observasional yaitu pelaksanaan dan pengamatan secara langsung pada progam penanganan reproduksi sapi Peranakan Ongole betina yang dilakukan oleh Satker Sumberejo Kendal. Progam yang dilaksanakan adalah sinkronisasi berahi menggunakan MPA 50 mg/ekor.

\section{Materi Penelitian}

Penelitian dilaksanakan di Satker Sumberejo, Kecamatan Kaliwungu Kabupaten Kendal. Penelitian di mulai bulan Juni - Juli 2016 yang meliputi persiapan, sinkronisasi berahi dan pengambilan data.

Materi penelitian 53 ekor sapi betina PO dengan organ reproduksi normal, tidak bunting, tidak menyusui dan berbagai umur 2-12 tahun. Bahan yang digunakan adalah spon vagina buatan dengan diameter 5 meter dan panjang $6 \mathrm{~cm}$, MPA $50 \mathrm{mg} / \mathrm{spon}$, alkohol untuk mensterilkan alat, pelumas merek $v$-gell untuk mengolesi aplikator pemasang spon vagina, tisu untuk membersihkan peralatan penelitian dan vulva, betadin untuk mengolesi spon yang akan dipasang dalam usaha meminimalisir perkembangan mikroorganisme di vagina.

Alat yang digunakan adalah aplikator untuk memasukkan spon, senter untuk penerangan ketika deteksi berahi pada malam hari, termometer untuk mengukur suhu vulva.

\section{Pelaksanaan Penelitian}

Sapi yang digunakan sebagai materi penelitian dikelompokkan menjadi 3 kelompok umur dengan melihat data rekording. Pengelompokan induk sapi menurut penelitian Praharni (2011) bahwa sapi umur 2-5 tahun produktif dan mengalami puncak produktif serta akan menurun seiring dengan bertambahnya umur sapi lebih dari 7

Performa Berahi Sapi PO ... (Mustagfiroh et al.) 
Tabel 1. Jumlah sapi berahi yang disinkronisasi dengan MPA berbagai umur.

\begin{tabular}{lccc}
\hline Umur & Jumlah Sapi & Tidak Berahi (ekor \%) & Berahi (ekor \%) \\
\hline $2-5$ & 10 & $8(80,00)$ & $2(20,00)$ \\
$>5-9$ & 6 & $3(50,00)$ & $3(50,00)$ \\
$>9-12$ & 37 & $24(65,00)$ & $13(35,00)$ \\
Jumlah & 53 & $35(66,04)$ & $18(33,96)$ \\
\hline
\end{tabular}

tahun. Maka pengelompokan umur berdasar dari penelitian Praharni (2011) adalah umur 2-5 tahun termasuk produktif, lebih dari 5-9 tahun kurang produktif dan lebih dari 9-12 tahun tidak produktif.

Sinkronisasi berahi menggunakan spon berukuran panjang $6 \mathrm{~cm}$ dengan diameter 5 $\mathrm{cm}$ berbentuk silinder yang berisi hormon MPA. Spon diberi betadin salep untuk mengurangi pertumbuhan bakteri dalam vagina. Kemudian spon dimasukkan ke vagina menggunakan aplikator yang sudah disterilkan dengan alkohol dan untuk mempermudah memasukkan diolesi v-gell. Spon vagina ditanam dalam vagina selama 17 hari. Pencabutan spon dilakukan pada hari ke 18 dihitung dari saat pemasangan. Sapi dipelihara secara intensif dikandang yang didalamnya disediakan tambatan untuk memisahkan antara sapi satu dengan yang lainnya. Pakan yang diberikan berupa campuran rumput lapang dengan rumput gajah, jerami padi dan konsentrat yang masing-masing 4, 1,5 dan 2,5 $\mathrm{kg}$ perekor.

Pengambilan data tentang tanda-tanda berahi sapi dilakukan setiap hari tiga kali yaitu pagi jam 08.00, siang jam 14.00 dan malam jam 19.00 sejak 24 jam setelah spon dicabut.

\section{Parameter Penelitian}

Parameter penelitian yang diamati dan cara pengukurannya adalah

1. Banyaknya sapi berahi yaitu jumlah sapi berahi yang ditandai dengan munculnya tanda berahi yaitu perubahan warna, bengkak dan suhu vulva dinyatakan dengan persen (Sutiyono et al., 2008).

2. Kecepatan berahi yaitu selang waktu dari pencabutan spon vagina sampai salah satu tanda berahi muncul yang dinyatakan jam (Sutiyono et al., 2008). Kecepatan berahi dihitung dengan rumus berikut:

$\mathrm{KB}=\mathrm{WMB}-\mathrm{WPS}$.

Keterangan :

KB : Kecepatan Berahi

WBM: Waktu Munculnya Berahi

WPS : Waktu Pencabutan Spon

3. Lama berahi yaitu selang waktu dari munculnya salah satu tanda berahi sampai semua tanda berahi tidak kelihatan atau menghilang. (Sutiyono et al., 2008). Lama berahi dihitung dengna rumus:

$\mathrm{LB}=\mathrm{WTBH}-\mathrm{WMTB}$

Keterangan :
LB :Lama Berahi
WTBH :Waktu Tanda Berahi Hilang
WMBTB :Waktu Munculnya Tanda Berahi

Analisis data hasil penelitian banyaknya sapi yang berahi menggunakan analisis secara deskriptif sedangkan lama berahi dan kecepatan berahi antara kelompok umur dianalisis menggunakan one way anova (analisa varian satu arah) taraf kepercayaan 95\% dengan bantuan progam Statistical Product Services Solution (SPSS 16).

\section{HASIL DAN PEMBAHASAN}

\section{Jumlah Sapi yang Berahi}

Rata-rata persentase sapi yang berahi pengaruh sinkronisasi berahi menggunakan MPA sebanyak 33,96\% (Tabel 1) dan tergolong rendah. Sutiyono et al. (2014) menyatakan bahwa persentase berahi sapi dara berumur tua dan sapi induk yang disinkronisasi menggunakan hormon progesteron masing- 
Tabel 2. Rataan kecepatan berahi sapi yang disinkronisasi dengan MPA berbagai umur.

\begin{tabular}{lcc}
\hline Umur (tahun) & Jumlah Sapi (ekor) & Rataan (jam) \\
\hline $2-5$ & 2 & 528,0 \\
$>5-9$ & 3 & 288,0 \\
$>9-12$ & 13 & 322,5 \\
\hline
\end{tabular}

masing $91,67 \%$ dan $73,53 \%$. Sapi yang berahi akibat sinkronisasi dengan metode implantasi spon yang diberi MPA di vagina disebabkan karena setelah spon dicabut tidak ada hambatan untuk produksi FSH sehingga progesteron dalam darah turun. FSH mampu merangsang pertumbuhan folikel sehingga dapat terjadi berahi. Toelihere (1985) menyatakan bahwa ketika spon dicabut maka hambatan terhadap produksi FSH dan LH terhenti, kemudian beberapa hari sapi akan berahi. Persentase sapi yang tidak berahi adalah $66,04 \%$. Sapi yang tidak berahi dapat disebabkan karena kekurangan nutrisi pada ternak. Kekurangan protein pada ternak dapat menyebabkan munculnya tanda berahi yang kurang jelas. Protein merupakan prekusor biosintesis hormon gonadotropin yang menghasilkan FSH dan LH yang memicu timbulnya berahi dan ovulasi. Abidin et al. (2012) menyatakan bahwa nutrisi sangat diperlukan untuk fisiologis reproduksi pada ternak. Nutrisi pakan yang kurang menyebabkan terganggunya sintesa dan regulasi hormon reproduksi yang mengakibatkan respon berahi kurang jelas.

\section{Kecepatan Berahi}

Rataan kecepatan timbulnya berahi sapi PO berbagai umur hasilnya antara 288528 jam dan tergolong tidak normal (Tabel 2). Hasil penelitian Mardiansyah et al. (2016), kecepatan timbulnya berahi sapi Bali dara dan induk yang diimplantasi menggunakan hormon progesteron adalah 41,53 jam dan 50,67 jam. Keterlambatan munculnya berahi dapat disebabkan kurangnya asupan nutrisi pada ternak sehingga menyebabkan terjadinya gangguan reproduksi pada ternak. Toelihere (1985) menyatakan bahwa gangguan reproduksi pada ternak berhubungan dengan sekresi FSH yang berperan dalam pertumbuhan folikel untuk produksi hormon estrogen yang berfungsi untuk menimbulkan berahi pada ternak. Ismail (2009) menyatakan bahwa pertumbuhan dan perkembangan folikel ditentukan oleh kadar FSH dalam darah.

Analisis rataan kecepatan berahi pada setiap kelompok umur sapi menunjukkan tidak ada perbedaan. Hasil penelitian pada Tabel 2 menunjukkan rataan kecepatan berahi kelompok umur 2-5 tahun lebih lambat (528 jam) dibandingkan kelompok umur lain. Hal ini dapat disebabkan faktor luar seperti skor kondisi tubuh yang rendah. Saili et al. (2011) menyatakan bahwa kecepatan munculnya berahi dipengaruhi oleh faktor non perlakuan seperti faktor kondisi ternak dan faktor individu. Lamanya kemunculan gejala berahi dapat disebabkan karena sapi PO yang berahi dengan umur 2-5 tahun ada yang belum pernah beranak sehingga respon terhadap hormon sinkronisasi rendah karena sel saluran reproduksinya belum cukup berkembang. Menurut Handayani et al. (2014), sapi dengan paritas 0 dan paritas 1 diduga memiliki sel saluran reproduksi yang belum cukup berkembang yang menyebabkan respon terhadap hormon untuk sinkroisasi kurang.

\section{Lama Berahi Sapi}

Lama berahi merupakan jarak waktu antara timbulnya gejala berahi pertama sampai dengan gejala berahi tidak muncul lagi. Hasil analisis uji one way anova menunjukkan tidak ada perbedaan rataan lama berahi antar kelompok umur sapi (Tabel 3). Rataan lama berahi antara 531-693 menit, tergolong tidak normal. Menurut Toelihere (1985), rata-rata lama berahi sapi adalah 18 jam. Pendeknya durasi berahi pada sapi dapat disebabkan karena gangguan reproduksi

Performa Berahi Sapi PO ... (Mustagfiroh et al.) 
Tabel 3. Rataan lama berahi sapi yang disinkronisasi dengan MPA berbagai umur.

\begin{tabular}{lcc}
\hline Umur (tahun) & Jumlah Sapi (ekor) & Rataan (menit) \\
\hline $2-5$ & 7 & 693 \\
$>5-9$ & 9 & 586 \\
$>9-12$ & 2 & 531 \\
\hline
\end{tabular}

akibat kekurangan nutrisi. Handayani et al. (2014) menyatakan bahwa gangguan reproduksi pada ternak dapat mempengaruhi produksi estrogen. Tabel 3 menunjukkan bahwa kelompok umur $>9-12$ tahun memiliki lama estrus tersingkat yaitu 531 menit ( 8 jam 51 menit). Hal ini dapat disebabkan karena kondisi reproduksi sapi yang tergolong tua semakin menurun seiring bertambahnya umur sapi sehingga mempengaruhi produksi hormon reproduksi yang kurang maksimal. Zainuddin et al. (2015) menyatakan bahwa umur ternak terlalu tua yaitu $>10$ tahun kemampuan reproduksi induk sudah menurun baik fisiologis maupun hormonalnya. Hormon reproduksi seperti estrogen berfungsi untuk menimbulkan berahi sehingga keberadaan estrogen saat berahi menentukan panjangnya masa berahi. Tagama (1995) menyatakan bahwa kadar estrogen yang tinggi dalam tubuh menyebabkan masa berahi lebih lama.

\section{KESIMPULAN}

Berdasarkan hasil penelitian dapat disimpulkan bahwa performa berahi sapi PO berbagai umur yang disinkronisasi dengan MPA tidak memberikan perubahan terhadap performa berahinya.

\section{DAFTAR PUSTAKA}

Abidin, Z., Y.S. Ondho dan Sutiyono. 2012. Penampilan berahi sapi Jawa berdasarkan poel 1, poel 2 , dan poel 4 . J. Anim. Agric. 1 (2): 86 - 92.

Badan Pusat Statistik Jakarta Pusat. 2016. Populasi Sapi Potong menurut Provinsi 2012-2016. Badan Pusat Statistik. Jakarta.
Britt, J. H. 1987. Synchronization of Ovulation. In: E. S. E. Hafez (ed). Reproduction in Farm Animal. Fifth Ed. Lea dan Febiger. Philadelphia.

Handayani, U. F., M. Hartono dan Siswanto. 2014. Respon kecepatan timbulnya estrus dan lama estrus pada sapi Bali setelah dua kali pemberian Prostaglandin F2 $\alpha$ (PGF2 $\alpha$ ). J. Ilmiah Peternakan Terpadu. 2 (1) : 33-39.

Hastono. 2000. Penyerempakan berahi pada domba dan kambing. J. Anim. Prod. 2 (1): 1-8.

Ismail, M. 2009. Onset dan intensitas estrus kambing pada umur yang berbeda. J. Agroland. 16 (2) : 180-186.

Pane, I. 1993. Pemuliabiakan Ternak Sapi. Gramedia Pustaka Utama. Jakarta.

Praharni, L. 2011. Respon sinkronisasi estrus sapi Brahman dan persilangannya. Seminar Nasional Teknologi Peternakan dan Veteriner. Bogor 7-8 Juni 2011. Puslitbang Peternakan, Bogor. 68-74.

Rizal, M. dan Herdis. 2008. Inseminasi Buatan pada Domba. Rineka Cipta. Jakarta.

Shinjo, A. 1990. First Course in Statistics First Edition. University of the Ryukyus Nishihara-Cho, Okinawa

Soejosopoetro,B. 2011. Studi tentang pemotongan sapi betina di RPH Malang. J. Ternak Tropika. 12 (1) : 2326.

Sutiyono, E. T. Setiatin, Kuncara dan S. Mayasari. 2008. Pengaruh pemberian ekstrak hipofisa terhadap berahi dan fertilitas pada domba yang berahinya diserentakan dengan progesteron. J. Indon. Trop. Anim. Agric. 33: 35-41.

Sutiyono, D. Samsudewa dan A. Suryawijaya. 
2014. Dampak sinkronisasi berahi menggunakan progesteron terhadap berahi dan kebuntingan sapi betina milik rakyat Kabupaten Sukoharjo. J. Litbang Provinsi Jawa Tengah. 12 (1): 27-32.

Tagama, T. R. 1995. Pengaruh hormon estrogen, progesteron dan prostaglandin f2 alfa terhadap aktivitas birahi sapi PO dara. J. Ilmiah Penelitian Ternak Grati. 4 (1): 7-11.

Toelihere, M. R. 1985. Fisiologi Reproduksi pada Ternak. Angkasa Bandung, Bandung

Toelihere, M. R. 1997. Peran bioteknologi reproduksi dalam pembinaan produksi peternakan di Indonesia. Makalah disampaikan pada pertemuan teknis dan koordinasi Produksi Peternakan Nasional. Cisarua, 4 - 6 Agustus 1997. Halaman 45-80.

Zainuddin, M., M. N. Ihsan dan Suyadi. 2015. Efisiensi reproduksi sapi perah $\mathrm{PFH}$ pada berbagai umur Di CV. Milkindo Berka Abadi Desa Tegalsari Kecamatan Kepanjen Kabupaten Malang. J. IlmuIlmu Peternakan. 24 (3): 32 - 77.

Zulkarnain., Sutiyono dan E. T Setiatin. 2015. Pemanfaatan ekstrak hipotalamus kambing sebagai upaya optimalisasi kesuburan kambing Kejobong betina. J. Vet. 16 (3) : 343-350. 